\title{
In Vitro Bioavailability of Mineral Nutrients in Breakfast Cereals
}

\author{
Anna Leśniewicz (Corresponding author), Mariola Kretowicz, Kamila Wierzbicka \& Wiesław Żyrnicki \\ Analytical Chemistry Division, Faculty of Chemistry, Wrocław University of Technology \\ Wybrzeże Wyspiańskiego 27, Wrocław 50-370, Poland \\ Tel: 48-713-202-494 E-mail: anna.lesniewicz@pwr.wroc.pl
}

\author{
Received: October 13, $2011 \quad$ Accepted: October 26, $2011 \quad$ Published: May 1, 2012 \\ doi:10.5539/jfr.v1n2p291 \\ URL: http://dx.doi.org/10.5539/jfr.v1n2p291
}

The work was financed by a statutory activity subsidy from the Polish Ministry of Science and Higher Education for the Faculty of Chemistry of Wroctaw University of Technology

\begin{abstract}
The bioavailability of both micro- and macroelements was investigated under conditions simulating the digestion processes in the human alimentary system. A one-step enzymatic extraction was applied using buffered solutions containing pepsin, trypsin, $\alpha$-amylase or pancreatin, which are enzymes that hydrolyse different nutritional food components such as peptides, carbohydrates and lipids, as the extractant. Corn flakes and multigrain breakfast cereals containing taste additives from a local market in the Wroclaw agglomeration were selected for study as an important kind of ready-to-eat meal. The most popular brands (corn flakes from Nestlé, Mlekołaki and Hanne as well as wheat-based breakfast cereals from Chocapic, Nesquik and Fitness) were analysed. Microwave digestion was employed for sample preparation, and the total concentrations of both micronutrients $(\mathrm{Al}, \mathrm{Ca}, \mathrm{Cu}$, $\mathrm{Fe}, \mathrm{Mg}, \mathrm{Mn}, \mathrm{P}, \mathrm{Sr}$ and $\mathrm{Zn}$ ) and metals released during enzymatic in vitro digestion were measured by inductively coupled plasma-optical emission spectrometry (ICP-OES). Analysis of a Standard Reference Material was performed to validate the applied analytical procedure. Fractionation of the metals bound to the peptides, lipids and carbohydrates was evaluated and discussed.
\end{abstract}

Keywords: Micronutrients bioavailability, Enzymatic extraction, Fractionation, Breakfast cereals, Micro- and macroelements

\section{Introduction}

Oral ingestion is the only natural path to supply humans with trace elements and other essential nutrients, which are indispensable for growth, normal physiological functioning and the maintenance of life because the body cannot synthesise them. The best way to provide a sufficient amount of nutrients is to ensure the consumption of an adequately balanced diet. Therefore, quality control of the identity, purity and concentration of characterizing compounds ensures the quality, safety and efficacy of food products. It is widely known that the toxicity of metals and metalloids depends on their concentration and bioavailability. Consequently, the identification and quantitative determination of the elemental chemical forms should be assessed in addition to the total metal content. One of the possibilities for the verification of environmental risks to humans from metals present in food is to measure their bioavailability (bioaccessibility). Bioaccessibility is the maximum amount of the compound released from the matrix during gastrointestinal digestion that becomes available for intestinal absorption (Oomen et al., 2002).

For that purpose, in vitro digestion procedures were developed based on human physiology.

Digestion using simulated gastric and intestinal fluids provides valuable information on mineral fractionation and allows the estimation of their bioavailability (Elless, Blaylock, Huang \& Gussman, 2000). Simulation of stomach conditions consists mainly of reconstructing the essential constituents of gastric juices. Pepsin, which occurs in gastric juices, is a proteolytic enzyme that digests proteins in the highly acidic ( $\mathrm{pH}$ between 2 and 3 ) environment of the stomach. This enzyme begins digestion by splitting proteins into smaller pieces. The simulated gastric juice, i.e., a solution containing pepsin, sodium chloride and hydrochloric acid, was used to release metals from food and dietary supplements (Ponce de Leon, Sutton, Caruso \& Uden, 2000; Silva et al., 2001; Reyes et al., 2006; Bermúdez-Soto, Tomás-Barberán \& Garciá-Conesa, 2007; Kulkarni, Acharya, Rajurkar 
\& Reddy, 2007). Intestinal digestion involves the activity of trypsin, amylase, pancreatin, bile salts and bicarbonates and takes place in the small intestine. At this phase in digestion, proteins, polysaccharides and fats are hydrolysed into products that can be absorbed, i.e., surpass the intestinal membrane. Enzymatic digestion procedures replicating intestinal digestion consist of the application of both single enzymes, such as trypsin (Pardo-Martínez, Viñas, Fisher \& Hill, 2001; Peña-Farfal et al., 2005), $\alpha$-amylase (Caruso, Heitkemper \& Hymer, 2001; Peña-Farfal et al., 2004 ), lipase (Peña-Farfal et al., 2004) and pronase (Dernovics, Stefánka \& Fodor, 2002), or their natural combination, pancreatin (Miller, Schricker, Rasmussen \& Van Campen, 1981; Pardo-Martínez, Viñas, Fisher \& Hill, 2001; Peña-Farfal et al., 2004; Kulkarni, Acharya, Rajurkar \& Reddy, 2007) and synthetic mixtures, such as pancreatin with $\alpha$-amylase (Azenha \& Vasconcelos, 2000; Reyes et al., 2006) or pronase with amylase (Casiot, Szpunar, Łobiński, Potin-Gautier, 1999).

All the enzymatic extraction procedures were conducted at $37^{\circ} \mathrm{C}$, which is similar to the normal body temperature. To simulate the gastrointestinal movement and mixture of food during enzymatic hydrolysis, the samples were shaken (Peña-Farfal et al., 2005; Reyes et al., 2006), stirred, either mechanically or magnetically (Ponce de Leon, Sutton, Caruso \& Uden, 2000; Caruso, Heitkemper \& Hymer, 2001; Kulkarni, Acharya, Rajurkar \& Reddy, 2007), or swirled (B'Hymer \& Caruso, 2000) for a set period of time primarily in a water bath. Usually, procedures simulating gastric digestion last from 1 to 6 hours (Peña-Farfal et al., 2005; Peña-Farfal et al., 2005; Kulkarni, Acharya, Rajurkar \& Reddy, 2007), whereas the samples are incubated in the intestinal juices for 1 to 24 hours (Pardo-Martínez, Viñas, Fisher \& Hill, 2001; Dernovics, Stefánka \& Fodor, 2002; Peña-Farfal et al., 2004). A distinct reduction of the length of the enzymatic hydrolysis procedure to 30 minutes was achieved using ultrasonic energy (Peña-Farfal et al., 2005).

Enzymatic extraction procedures were employed to assess the bioaccessibility of metals in various food and environmental samples, such as mixtures of food (meals) (Miller, Schricker, Rasmussen \& Van Campen, 1981), baby foods (Pardo-Martínez, Viñas, Fisher \& Hill, 2001), fish (swordfish, sardine and tuna) (B'Hymer \& Caruso, 2000), mussel soft tissues (Peña-Farfal et al., 2004), edible seaweeds (Peña-Farfal et al., 2005), bovine milk (Silva et al., 2001), freeze-dried apples (Caruso, Heitkemper \& Hymer, 2001), chokeberries (Bermúdez-Soto, Tomás-Barberán \& Garciá-Conesa, 2007), wheatgrass (Kulkarni, Acharya, Rajurkar \& Reddy, 2007), mushrooms (Dernovics, Stefánka \& Fodor, 2002), yeast and yeast-based food supplements (Casiot, Szpunar, Łobiński \& Potin-Gautier, 1999; B'Hymer \& Caruso, 2000; Reyes, Encinar, Marchante-Gayón, Alonso \& Sanz-Medel, 2006; Bermúdez-Soto, Tomás-Barberán \& Garciá-Conesa, 2007), wine (Azenha \& Vasconcelos, 2000) and soil (Oomen et al., 2002).

The majority of the undertaken research focused on the determination of only one or a few different elements. Essential micronutrients, such as $\mathrm{Ca}$ (Silva et al., 2001), $\mathrm{Cu}$ (Miller, Schricker, Rasmussen \& Van Campen, 1981), Fe (Miller, Schricker, Rasmussen \& Van Campen, 1981; Silva et al., 2001), Mg (Silva et al., 2001), Se (Ponce de Leon, Sutton \& Caruso, Uden, 2000) and Zn (Silva, Lopes, Nóbrega, Souza \& Nogueira, 2001), or toxic elements, such as As (Pardo-Martínez, Viñas \& Fisher, Hill, 2001; Peña-Farfal et al., 2004), Hg (Cabañero, Madrid \& Cámara, 2004) and $\mathrm{Pb}$ (Azenha \& Vasconcelos, 2000), were investigated. Only a few studies were performed using enzymatic extraction procedures for multi-elemental analysis, which can lead to measurements based on the quantification of more than eight different elements (Oomen et al., 2002; Peña-Farfal et al., 2004; Peña-Farfal et al., 2005). The concentration of both the major and trace elements examined was mainly assessed using spectroscopic methods, in particular FAAS (Azenha \& Vasconcelos, 2000), HG-AAS (Pardo-Martínez, Viñas, Fisher \& Hill, 2001), AFS (Dernovics, Stefánka \& Fodor, 2002; Cabañero, Madrid \& Cámara, 2004), ICP-OES (Dernovics, Stefánka \& Fodor, 2002; Peña-Farfal et al., 2005, ICP-MS (Casiot, Szpunar, Łobiński \& Potin-Gautier, 1999; Cabañero, Madrid \& Cámara, 2004; Reyes et al., 2006), INNA (Kulkarni, Acharya, Rajurkar \& Reddy, 2007).

The aim of the present work, continuation of of our recent study (Leśniewicz, Kretowicz, Wierzbicka, Żyrnicki, 2009), was to determine the mineral composition, nutritive value and the (in vitro) bioavailability of minerals and trace elements in ready-to-eat breakfast cereals by applying enzymatic digestion procedures. Two types of products, corn and multigrain breakfast cereals, were analysed. The enzymes in the gastric and pancreatic juices were used to investigate metal fractionation. The extraction effectiveness was investigated to evaluate the liberation of metals through the enzymatic hydrolysis of macronutrients, such as peptides, lipids and carbohydrates, present in the corn flakes and flavoured breakfast cereals examined. 


\section{Materials and Methods}

\subsection{Samples}

Popular brands of breakfast cereals - ready-to-eat food grain products playing important role in children and adolescent diet - purchased from the local market in the Wrocław commercial area were studied. The packages containing the corn and multigrain breakfast cereals were randomly selected for analysis, and a detailed description of the analysed products is given in Table 1. The Standard Reference Material, Corn Flour INCT-CF-3, was used to assess the accuracy and precision of the applied procedures.

\subsection{Reagents, glassware and plastics}

All chemicals used in this study were analytical grade and tested for possible contamination. For sample digestion, concentrated $\mathrm{HNO}_{3}$ (Merck KGaA, Germany) and 30\% (m/v) $\mathrm{H}_{2} \mathrm{O}_{2}$ (Polish Chemical Reagents, Poland) were used. Pepsin from a hog's stomach, trypsin from a porcine pancreas, $\alpha$-amylase from a hog's pancreas and pancreatin from a porcine pancreas (BioChemika, Fluka) were used to prepare the extractants. Aqueous standard solutions were prepared by diluting the ICP multi-element standards (Merck KGaA, Germany). All dissolutions and dilutions were performed using $18.3{\mathrm{M} \Omega \mathrm{cm}^{-1}}^{-}$water (EASYpure ${ }^{\mathrm{TM}}$ system, Barnstead, Thermolyne Corporation, USA).

Glass and plastic test tubes and bottles were washed with distilled water, cleaned with diluted nitric acid in an ultrasonic bath and rinsed several times with deionized water.

\subsection{Extraction method - enzymatic hydrolysis}

A conventional, one-step, solid-liquid leaching was performed at $37^{\circ} \mathrm{C}$ in a water bath shaker (elpan-Laboratory Instruments, type 357). The following extractants were used:

1. a solution containing pepsin, hydrochloric acid and sodium chloride (1.6 g pepsin, $1,0 \mathrm{~g}$ of $\mathrm{NaCl}$ and 3.5 $\mathrm{mL}$ of $37 \% \mathrm{HCl}$ made up to the $500 \mathrm{~mL}$ with deionized water (Ponce de Leon, Sutton, Caruso, Uden, 2000)) with a composition similar to gastric juices;

2. an $\alpha$-amylase buffered solution $(1,4286 \mathrm{~g} \alpha$-amylase dissolved in phosphate buffer solution, $\mathrm{pH}=7.1$ and made up to $500 \mathrm{~mL}$ with the same buffer solution (Harper, Rodwell, Mayer, 1983));

3. a buffered solution containing trypsin $(1,4286 \mathrm{~g}$ trypsin dissolved and filled up to the $500 \mathrm{~mL}$ with phosphate buffer solution, $\mathrm{pH}=7.5$ (Peña-Farfal et al., 2005));

4. a solution containing pancreatin $(1,4286 \mathrm{~g}$ pancreatin dissolved in phosphate buffer solution, $\mathrm{pH}=7.5$ and made up to $500 \mathrm{~mL}$ with the same solution (Peña-Farfal et al., 2004; Intawongse \& Dean, 2006)).

In a plastic test-tube, $20.0 \mathrm{~mL}$ of the extractant solution was added to $0.5 \mathrm{~g}$ of the dry material. The closed tube was shaken for either $2 \mathrm{~h}$ (for the pepsin solution) or $6 \mathrm{~h}$ (for trypsin, $\alpha$-amylase and pancreatin solutions) at $37^{\circ} \mathrm{C}$ on a mechanical shaker at a speed of 200 r. p. m.. The supernatant was separated from the solid residue by centrifuging for 15 minutes at 9000 r.p.m. (High Speed Brushless Centrifuge - MPW 350). All of the extracts investigated were stored in clean polyethylene bottles at $4{ }^{\circ} \mathrm{C}$ before analysis.

Five parallel analyses were performed for each examined sample. For each set of five replicates of the digested or extracted samples, a blank was simultaneously subjected to the complete procedure, analysed and used to correct the analytical signals. All of the extraction procedures were applied to the examined samples twice.

\subsection{Measurement of element contents}

A standard microwave digestion procedure was used prior to the total concentration measurements. The concentrations of elements (i.e., $\mathrm{Al}, \mathrm{Ca}, \mathrm{Cu}, \mathrm{Fe}, \mathrm{Mg}, \mathrm{Mn}, \mathrm{P}, \mathrm{Sr}$ and $\mathrm{Zn}$ ) in the digests and extracts were measured using inductively coupled argon plasma-optical emission spectrometry (ICP-OES). A Jobin-Yvon 38S spectrometer was equipped with a cross-flow nebuliser and Scott-type spray chamber for the digest measurements and a V-groove nebuliser and cyclonic chamber for the extracted samples. The instrument operating parameters and analytical line wavelengths used are shown in Table 2.

\section{Results and Discussion}

Many types of breakfast cereals are produced using a variety of taste additives. As a general rule, the mineral content is different in corn flakes and multi-grain breakfast cereals enriched with additives. Therefore, for studies of mineral bioavailability, the three products based on wheat, rice and corn grains as well as three based only on corn flour (see Table 3) with the highest element content were selected based on our previous study (Leśniewicz, Kretowicz, Wierzbicka \& Żyrnicki, 2009) . 
Enzymatic extraction experiments were performed to study the availability of micronutrients in these breakfast cereals simulating the processes of the digestion in the human gastrointestinal system.

The enzymes responsible for gastric and intestinal digestion were used for these studies (Harper, Rodwell \& Mayer, 1983).

Pepsin, an enzyme present in gastric juice, as well as amylase, trypsin and pancreatin, which exist in pancreatic juice, were applied during this study. Pepsin and trypsin break down dietary proteins into their component parts, i.e., peptides and amino acids, which can then be readily absorbed by the intestinal lining. Amylase degrades starches into sugars. Pancreatin, a mixture of trypsin, amylase and lipase, hydrolyses proteins into oligopeptides, starches into oligosaccharides and maltose and triglycerides into fatty acids and glycerols (Harper, Rodwell \& Mayer, 1983).

The enzymatic hydrolysis efficiency was calculated as a ratio of the metal concentration in the extract to the element concentration in the samples after complete decomposition in a microwave system (Leśniewicz, Kretowicz, Wierzbicka \& Żyrnicki, 2009)

The results of the liberation of metals from both the examined corn flakes and multi-grain, flavoured breakfast cereals by the enzymatic activity are shown in Figures 1-4.

The activity of pepsin in an $\mathrm{HCl}$ solution with $\mathrm{pH}=2$ resulted in a high mineral extraction effectiveness from breakfast cereals made of wheat, rice and corn. Over $80 \%$ of the $\mathrm{Zn}, \mathrm{P}, \mathrm{Mn}, \mathrm{Mg}, \mathrm{Ca}$ and $\mathrm{Sr}$ content was removed from the organic matrix of the Chocapic, Nesquik and Fitness cereals. For these products, extraction efficiencies equal to or greater than $50 \%$ were observed for $\mathrm{Fe}$ and $\mathrm{Cu}$. Al was the only exception with at most $20 \%$ leaching into acidic pepsin solution. A similar tendency was observed for the examined corn flakes brands, albeit at a lower extraction efficiency. For those breakfast cereals, extraction using a solution of pepsin released more than $80 \%$ of the total $\mathrm{Zn}, \mathrm{Mn}, \mathrm{Ca}$ and $\mathrm{Sr}$ and $50 \%$ of the total P, Mg and $\mathrm{Cu}$. An effectiveness of less than $50 \%$ was observed for $\mathrm{Fe}$ for all examined corn flakes samples. Less than $20 \%$ of the total metal concentration determined by the pepsin solution was observed only in the case of Al. It is clear that ready-to-eat breakfast cereals can be a significant source of minerals, and micronutrients in such products are easily removable from the organic matrix by extraction under conditions similar to gastric digestion. Mineral susceptibility to digestion by acidic pepsin solutions is due to the metal that binds to the peptide or its specific connection to the organic matrix.

Moreover enzymes present in the pancreatic juice and, therefore, active during intestinal digestion were also studied. For evaluation of pancreatic enzymes influence on the examined samples, buffered solutions containing individual enzymes, i.e. trypsin, amylase and pancreatin were applied as extractants. As a general rule, higher enzymatic efficiencies were observed for corn flakes than for breakfast cereals made of wheat, rice and corn flour mixtures. The mineral leaching effectiveness of solutions containing trypsin, amylase and pancreatin for breakfast cereals made from corn is at least twice that for multigrain and flavoured breakfast cereals.

The effectiveness of the trypsin solutions was generally lower than those observed for extractants prepared from pepsin. In the case of multi-grain flakes, the efficiency of trypsin solution was at most $40 \%$. The extraction efficiencies for $\mathrm{Mn}, \mathrm{Mg}, \mathrm{Cu}$ and $\mathrm{Sr}$ from Chocapic, Nesquik and Fitness cereals were close to $30 \%$, and the concentrations of $\mathrm{Zn}$ and $\mathrm{Ca}$ in the extractant were the lowest, with only $10 \%$ of the total content being removable. For breakfast cereals made from corn, a high quantity, 30 to $100 \%$, of $\mathrm{Zn}, \mathrm{Mn}, \mathrm{Mg}$, $\mathrm{Ca}$ and $\mathrm{Cu}$ was removable from the organic matrix during extraction with the trypsin solution. Only in the case of $\mathrm{Al}$ and $\mathrm{Sr}$ fraction bound to proteins was low (approximately $10 \%$ was the leachable) for the trypsin solution).

Amylase, an enzyme that breaks down carbohydrates, was most effective at removing $\mathrm{Mn}, \mathrm{Mg}$ and $\mathrm{Cu}$ from multigrain cereals and $\mathrm{Zn}, \mathrm{Mn}, \mathrm{Mg}, \mathrm{Ca}, \mathrm{Cu}$ and $\mathrm{Al}$ from corn flakes. Extraction efficiencies were between 40 and $60 \%$ for multigrain cereals with taste additives and between 50 and $100 \%$ for corn flakes. Under these conditions, less than $20 \%$ of the total $\mathrm{Zn}$ and $\mathrm{Sr}$ and less than $5 \%$ of the total $\mathrm{Fe}, \mathrm{Ca}$ and $\mathrm{Al}$ was removable from the breakfast cereals made from wheat, rice and corn. By contrast, the lowest extraction efficiency observed for $\mathrm{Fe}$ and $\mathrm{Sr}$ in corn flakes was close to or higher than $20 \%$.

Application of the pancreatin solution removed up to $60 \%$ of the minerals from multigrain cereals and up to $100 \%$ from the corn-based products. This solution removed the largest percentage of $\mathrm{Mn}, \mathrm{Mg}, \mathrm{Cu}$ and $\mathrm{Al}$ from Chocapic, Nesquick and Fitness cereal brands. In the case of corn flakes, the highest extraction efficiency was observed for $\mathrm{Zn}, \mathrm{Mn}, \mathrm{Mg}, \mathrm{Cu}$ and $\mathrm{Al}$. The lowest extraction efficiencies for the pancreatin solution were observed for $\mathrm{Zn}, \mathrm{Fe}$ and $\mathrm{Ca}$ in the wheat, rice and corn flour flakes as well as for $\mathrm{Fe}$ and $\mathrm{Ca}$ in the corn-based breakfast cereals, with average values of 20 and $30 \%$, respectively. 
A comparison of the extraction effectiveness obtained for all of the pancreatic enzymes to the efficiency of the pepsin and hydrochloric acid mixture indicates that the enzymes active during intestinal digestion are less effective. Undoubtedly, the efficiency of the leaching process by trypsin, amylase and pancreatin solutions is higher for corn flakes than breakfast products based on wholemeal wheat, rice and corn. At the same time, the extraction efficiencies obtained for $\mathrm{Zn}, \mathrm{Mn}, \mathrm{Mg}, \mathrm{Cu}, \mathrm{Al}$ and $\mathrm{Sr}$ by amylase and pancreatin solutions are definitely higher than those obtained using the trypsin extractant for both kinds of products analysed. These results suggest a connection between the elements and the carbohydrate fraction hydrolysed by amylase or elements and the lipids degradable by the lipase in pancreatin (Harper, Rodwell \& Mayer, 1983). Only in the case of one element calcium - in multigrain breakfast cereals highest amount of was released by buffered solution containing trypsin, proteolitic enzyme.

Taking the origin and composition of the products into account with regards to their reaction to the extraction conditions, a few relationships could be pointed out. First of all, a proportional leaching of the elements from Chocapic, Nesquik and Fitness brand cereals by the amylase and pancreatin solutions was observed. For $\mathrm{Mn}, \mathrm{Mg}$ and $\mathrm{Sr}$, the highest extraction efficiency was from Nesquik and the lowest was from Fitness breakfast cereals. According to the manufacturer's data, Nesquik is made of wholemeal wheat, corn and rice flours as well as cocoa, whereas Fitness is composed of just wheat and rice grains. The maximum amount of $\mathrm{Cu}$ leachable by pancreatin extractants is obtained from Fitness, while the minimum is obtained from Nesquik. Metals are easily removable from Chocapic brand cereals, which are made of wholemeal wheat, wheat and rice flour with the addition of white chocolate and cocoa; however, the enzymatic extraction efficiency is not the greatest among the cereals studied, which is probably due to the presence of taste additives. The extraction efficiencies of the various kinds of corn flakes differ obviously, and the highest susceptibility of the matrix components to enzymatic hydrolysis were observed for Nestlé brand corn flakes, which have a higher corn content. At the same time, the lowest extraction efficiency was observed for $\mathrm{Sr}$ for all enzymes, both $\mathrm{Cu}$ and $\mathrm{Fe}$ for all pancreatic enzymes and $\mathrm{Al}$ for the pancreatin solution. The least amount of $\mathrm{Zn}$ was liberated from Hanne corn flakes for all extractants used. Additionally, the extraction efficiencies obtained for $\mathrm{P}, \mathrm{Mn}, \mathrm{Fe}, \mathrm{Mg}, \mathrm{Ca}$ and $\mathrm{Cu}$ from Hanne corn flakes were the least for the pepsin and $\mathrm{HCl}$ mixture. A constant proportion of $\mathrm{Fe}$ was leached by the pancreatic enzyme extractants.

Investigation of the Certified Reference Material, Corn Flour INCT-CF-3, served as an evaluation of the accuracy of the element concentration measurements, which was very high for most of the determined metals. For $\mathrm{Zn}, \mathrm{P}, \mathrm{Mg}$ and $\mathrm{Ca}$, the recovery was in the range 91-99,6\%, while $\mathrm{Mn}$ and $\mathrm{Sr}$ recovery was satisfactory if the uncertainties from the standard deviation were considered. Significant disagreement between the experimentally measured and certified element content was only observed for $\mathrm{Cu}$ and $\mathrm{Al}$.

Generally speaking, the precision of the measurements, expressed as RSD, was found to be less than $5 \%$ for the digests and $15 \%$ for the extracts.

\section{Conclusions}

A higher enzymatic extraction efficiency was observed for the acidic pepsin solution than for all of the examined pancreatic enzymes, which is due to the minerals either being present in an acid-soluble form or linked to the pepsin-degradable peptides.

For all elements, the effectiveness of metal liberation by pepsin in a $0.1 \mathrm{M} \mathrm{HCl}$ solution was considerably higher for wheat-based cereals than for corn flakes, and these efficiencies were comparable only for Fe. In the case of the multigrain cereal flakes, the extraction efficiencies for individual elements were close to $100 \%$ for the brands Chocapic, Nesquik and Fitness. In the case of corn flakes, various enzymatic extraction efficiencies were observed for each element from the different brands Mlekołaki, Nestlé and Hanne.

In contrast to the pepsin and $\mathrm{HCl}$ mixture, the extraction efficiencies of the trypsin solution were higher for the corn cereals than for the wheat-based products. The opposite tendency was observed only for Sr. The quantified liberation of individual elements by trypsin varied for all of the analysed products and was significantly lower than for the amylase and pancreatin solutions. The only exception was the response of $\mathrm{Ca}$ to the peptide-hydrolysing enzyme, which indicates that $\mathrm{Ca}$ is connected to the protein fraction.

Similarly to the behaviour of trypsin, buffered amylase and pancreatin solutions more efficiently liberated metals from corn flakes than from wheat cereals.

The various distributions of the different metals bound to the peptides, carbohydrates and lipids found here in ready-to-eat breakfast cereals were expected; however, the substantial differences between similar products supplied by different manufacturers was both unexpected and evident. In the case of wheat products, these 
differences can be explained by assuming the presence of various additives. However, the results achieved for corn cereals (e.g., the differences in the extraction efficiencies of $\mathrm{Zn}, \mathrm{Mn}, \mathrm{Mg}, \mathrm{Al}$ and $\mathrm{Sr}$ for amylase and $\mathrm{Zn}$ and $\mathrm{Sr}$ for trypsin or pancreatin) clearly indicate that the explanation is more complicated.

The relatively high liberation of $\mathrm{Sr}$, which is a toxic element - causing problems with bone growth, especially for children - by these enzymes seems to be an important fact worthy of attention. References

\section{References}

Azenha, M. A. G. O., \& Vasconcelos, M. T. S. D. (2000). Assessment of the $\mathrm{Pb}$ and $\mathrm{Cu}$ in vitro availability in wines by means of speciation procedures. Food Chem Toxicol, 38, 899-912. http://dx.doi.org/10.1016/S0278-6915(00)00082-X

B'Hymer, C., \& Caruso, J. A. (2000). Evaluation of yeas-based selenium food supplements using high-performance liquid chromatography and inductively coupled plasma mass spectrometry. J Anal Atom Spectrom, 12, 1531-1539. http://dx.doi.org/10.1039/B006437H

Bermúdez-Soto, M.-J., Tomás-Barberán, F.-A., \& Garciá-Conesa, M.-T. (2007). Stability of polyphenols in chokeberry (Aronia melanocarpa) subjected to in vitro gastric and pancreatic digestion. Food Chem., 102, 865-874. http://dx.doi.org/10.1016/j.foodchem.2006.06.025

Cabañero, A. I., Madrid, Y., \& Cámara, C. (2004). Selenium and mercury bioaccessibility in fish samples: an in vitro digestion method. Anal Chim Acta, 526(1), 51-61. http://dx.doi.org/10.1016/j.aca.2004.09.039

Caruso, J. A., Heitkemper, D. T., \& Hymer, C. B. (2001). An evaluation of extraction techniques for arsenic species from freeze-dried apple samples. Analyst, 126, 136-140. http://dx.doi.org/10.1039/b009825f

Casiot, C., Szpunar, J., Łobiński, R., \& Potin-Gautier, M. (1999). Sample preparation and HPLC separation approaches to seciation analysis of selenium in yeast by ICP-MS. J Anal Atom Spectrom, 14, 645-650. http://dx.doi.org/10.1039/A809027K

Dernovics, M., Stefánka, Zs., \& Fodor, P. (2002). Improving selenium extraction by sequential enzymatic processes for Se-speciation of selenium-enriched Agaricus bisporus. Anal Bioanal Chem, 372, 473-480. http://dx.doi.org/10.1007/s00216-001-1215-5

Elless, M. P., Blaylock, M. J., Huang, J. W., \& Gussman, Ch. D. (2000). Plants as a natural source of concentrated mineral nutritional supplements. Food Chem., 71, 181-188. PII: S0308-8146(00)00142-4

Harper, H. A., Rodwell, V. W., \& Mayer, P. A.(1983). Zarys chemii fizjologicznej, Państwowy Zakład Wydawnictw Lekarskich, Warszawa - in polish.

Intawongse, M., \& Dean, J. R. (2006). In-vitro testing for assessing oral bioaccessibility of trace metals in soil and food samples. Trends Anal Chem., 25 9), 876-886. http://dx.doi.org/10.1016/j.trac.2006.03.010

Kulkarni, S. D., Acharya, R., Rajurkar, N. S., \& Reddy, A. V. R. (2007). Evaluation of bioaccessibility of some essential elements from wheatgrass (Triticum aestivum L.) by in vitro digestion method. Food Chem, 103, 681-688. http://dx.doi.org/10.1016/j.foodchem.2006.07.057

Leśniewicz, A., Kretowicz, M, Wierzbicka, K., \& Żyrnicki, W. (2009). Inorganic micronutrients in food products of plant origin used for breakfast in Poland. Int $J$ Environ An Ch, 89(8-12), 621-634. http://dx.doi.org/10.1080/03067310902962494

Miller, D. D., Schricker, B. R., Rasmussen, R. R., \& Van Campen, D. (1981). An in vitro method for estimation of iron availability from meals. Am J Clinl Nutr, 34, 2248-2256.

Oomen, A. G., Hack, A., Minekus, M., Zeijdner, E., Cornelis, C., Schoeters, G., Verstraete, W., Van de Wiele, T., Wragg, J., Rompelberg, C. J. M., Sips, A. J. A. M., \& Van Wijnen J. H. (2002). Comparison of Five In Vitro Digestion Models To Study the Bioaccessibility of Soil Contaminants. Environ Sci Technol., 36 (15), 3326-3334. http://dx.doi.org/10.1021/es010204v

Pardo-Martínez, M., Viñas, P., Fisher, A., \& Hill, S. J. (2001). Comparison of enzymatic extraction procedures for use with directly coupled high performance liquid chromatography-inductively coupled plasma mass spectrometry for the speciation of arsenic in baby foods. Anal Chim Acta, 441, 29-36. PII: S0003-670(01)01070-4

Peña-Farfal, C., Moreda-Piñeiro, A., Bermejo-Barrera, A., Bermejo-Barrera, P., Pinochet-Cancino, H., \& de Gregori-Henríquez, I. (2004). Use of enzymatic hydrolysis for the multi-element determination in mussel soft tissue by inductively coupled plasma-atomic emission spectrometry. Talanta, 64, 671-681. http://dx.doi.org/10.1016/j.talanta.2004.03.042

Peña-Farfal, C., Moreda-Piñeiro, A., Bermejo-Barrera, A., Bermejo-Barrera, P., Pinochet-Cancino, H., \& de Gregori-Henríquez, I. (2005). Speeding up enzymatic hydrolysis procedures for the multi-element determination in edible seaweed. Anal Chim Acta, 548, 183-191. http://dx.doi.org/10.1016/j.aca.2005.06.004 
Ponce de Leon, C. A., Sutton, K. L., Caruso, J. A., \& Uden, P. C. (2000). Chiral speciation of selenoamino acids and selenium enriched samples using HPLC coupled to ICP-MS. J Anal Atom Spectrom, 15, 1103-1107. http://dx.doi.org/10.1039/B001069N

Reyes, L. H., Encinar, J. R., Marchante-Gayón, J. M., Alonso, J. I. G., \& Sanz-Medel, A. (2006). Selenium bioaccessibility assessment in selenized yeast after "in vitro" gastrointestinal digestion using two-dimensional chromatography and mass spectrometry. $J$ Chromatogr $A, \quad 1110, \quad 108-116$. http://dx.doi.org/10.1016/j.chroma.2006.01.088

Silva, F. V., Lopes, G. S., Nóbrega, J. A., Souza, G. B., \& Nogueira, A. R. A. (2001). Study of the protein-bound fraction of calcium, iron, magnesium and zinc in bovine milk. Spectrochim Acta B, 56, 1909-1916. http://dx.doi.org/10.1016/S0584-8547(01)00313-5

Wragg, J., Rompelberg, C. J. M., Sips, A. J. A. M., \& Van Wijnen J. H. (2002). Comparison of Five In Vitro Digestion Models To Study the Bioaccessibility of Soil Contaminants. Environ Sci Technol, 36 (15), 3326-3334. http://dx.doi.org/10.1021/es010204v

Table 1. Composition of the analysed breakfast cereals

\begin{tabular}{|c|c|c|c|}
\hline \multirow[b]{2}{*}{ Brand name } & \multirow[b]{2}{*}{ Producer } & \multicolumn{2}{|c|}{ Composition (according to producer data): } \\
\hline & & main compounds & $\begin{array}{l}\text { nutrients } \\
{[\mathrm{g} / 100 \mathrm{~g}]}\end{array}$ \\
\hline \multicolumn{4}{|l|}{ Corn flakes } \\
\hline $\begin{array}{l}\text { Corn flakes } \\
\text { MLEKOŁAKI }\end{array}$ & $\begin{array}{l}\text { Lubella S.A. } \\
\text { ul. Wronkowska } 1 \\
\text { 20-469 Lubin }\end{array}$ & $\begin{array}{l}\text { corn flour }(91.7 \%) \text {, barley } \\
\text { malt, fructose, glucose, salt, } \\
\text { emulsifier }\end{array}$ & $\begin{array}{l}\text { protein: } 6.6 \\
\text { carbohydrates: } 84.9 \\
\text { fat: } 2.3\end{array}$ \\
\hline $\begin{array}{l}\text { Corn flakes } \\
\text { Nestlé }\end{array}$ & $\begin{array}{l}\text { Cereal Partners Poland } \\
\text { Toruń-Pacific } \\
\text { ul. Szosa Lubicka } 38 \text { /58 } \\
87-100 \text { Toruń }\end{array}$ & $\begin{array}{l}\text { corn }(97 \%), \text { sugar, salt, } \\
\text { glucose, } \\
\text { emulsifier }\end{array}$ & $\begin{array}{l}\text { protein: } 7.3 \\
\text { carbohydrates: } 83.3 \\
\text { fat: } 1.5\end{array}$ \\
\hline $\begin{array}{l}\text { Corn flake } \\
\text { Hanne }\end{array}$ & $\begin{array}{l}\text { C. Halne Mühlenwerke } \\
\text { GmbH \& Co KG } \\
\text { Postfach } 100551 \\
\text { D-32505 Bad Oeynhaus }\end{array}$ & $\begin{array}{l}\text { corn }(91 \%) \text {, sugar, salt, } \\
\text { barley malt }\end{array}$ & $\begin{array}{l}\text { protein: } 7.3 \\
\text { carbohydrates: } 82.4 \\
\text { fat: } 1.2\end{array}$ \\
\hline \multicolumn{4}{|c|}{ Flavoured and multigrain flakes } \\
\hline Fitness & \multirow{3}{*}{$\begin{array}{l}\text { Brands manufactured } \\
\text { for NESTLÉ } \\
\text { Cereals Partners Poland, } \\
\text { Toruń-Pacific Sp. z o.o, } \\
\text { ul. Szosa Lubicka 38/58, } \\
\text { 87-100 Toruń. }\end{array}$} & $\begin{array}{l}\text { fitness flakes }(97 \%) \text { : cereal } \\
\text { grains - wheat }(39.1 \%) \text {, rice, } \\
\text { sugar, brown sugar syrup, } \\
\text { emulsifier, acidity regulator, } \\
\text { antioxidant }\end{array}$ & $\begin{array}{l}\text { protein: } 8.0 \\
\text { carbohydrates: } 79.8 \\
\text { fat: } 1.3\end{array}$ \\
\hline Chocapic Duo & & $\begin{array}{l}\text { flour }(52.9 \%): \text { wholemeal } \\
\text { wheat, wheat, rice, white } \\
\text { chocolate }(10.7 \%) \text {, cocoa } \\
(6.4 \%) \text {, glucose, barley malt, } \\
\text { palm oil, emulsifier }\end{array}$ & $\begin{array}{l}\text { protein: } 8.3 \\
\text { carbohydrates: } 74.4 \\
\text { fat: } 7.5\end{array}$ \\
\hline Nesquik & & $\begin{array}{l}\text { flours }(62.5 \%) \text { : wholemeal } \\
\text { wheat, corn, rice, sugar, } \\
\text { cocoa }(5.6 \%) \text {, glucose, palm } \\
\text { oil, salt, low-fat cocoa, acidity } \\
\text { regulator }\end{array}$ & $\begin{array}{l}\text { protein: } 7.3 \\
\text { carbohydrates: } 79.1 \\
\text { fat: } 3.8\end{array}$ \\
\hline
\end{tabular}


Table 2. Instrumental and operating conditions for ICP-AES

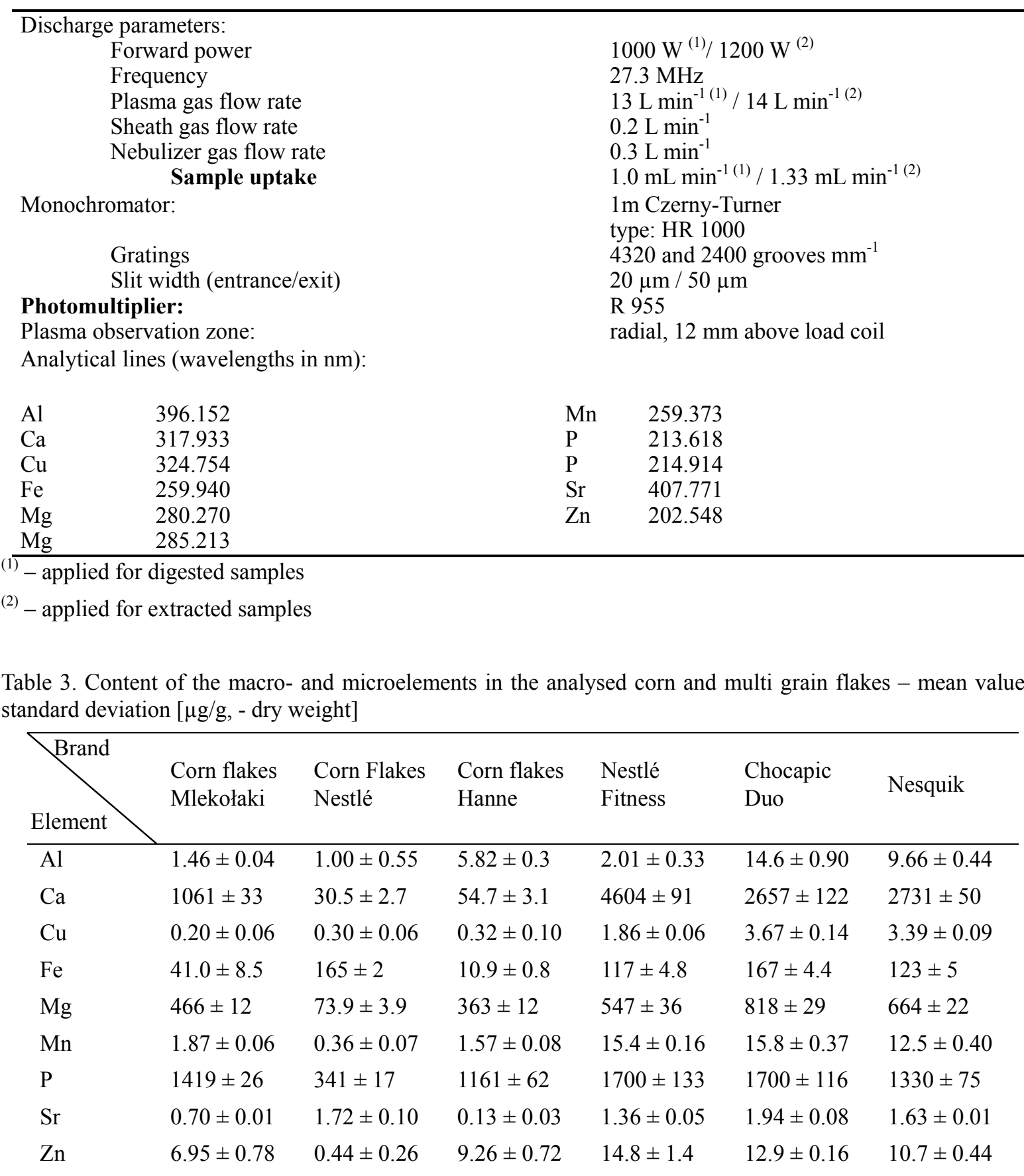



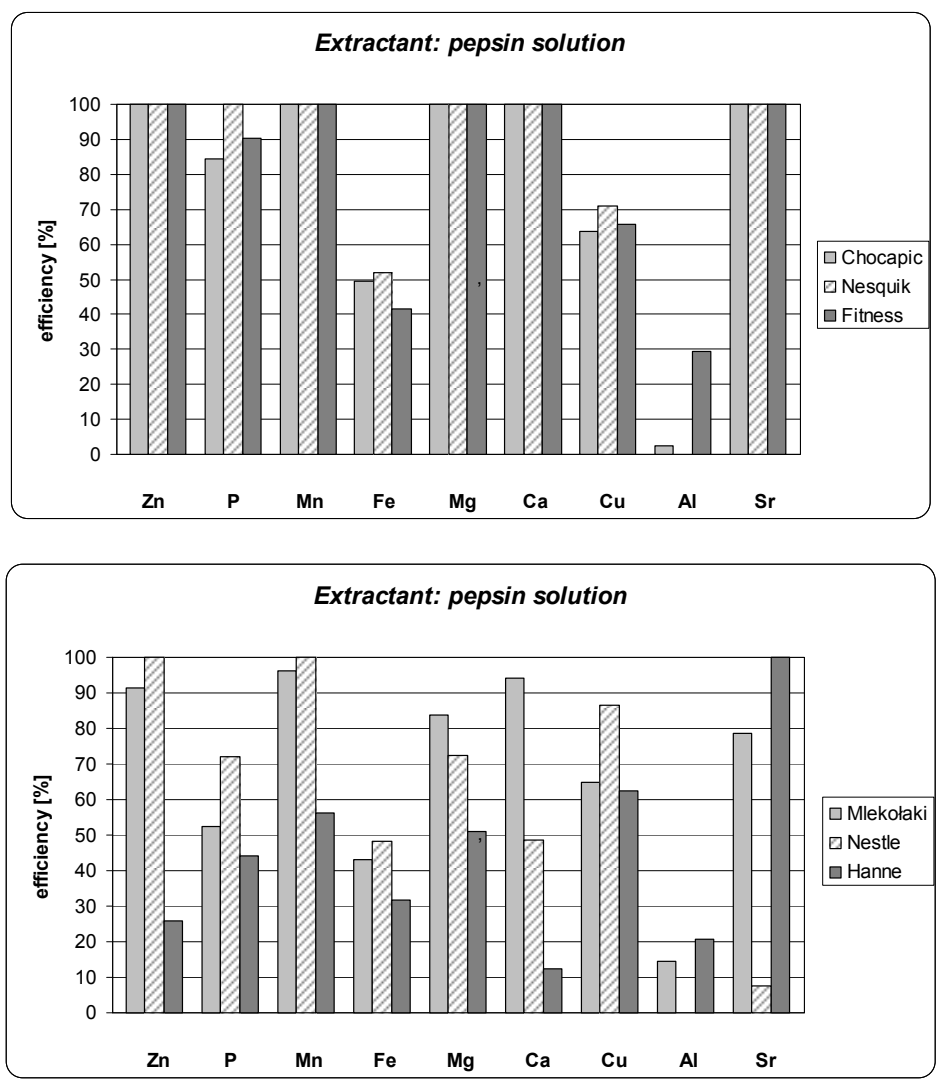

Figure 1. Enzymatic extraction efficiency for pepsin solution
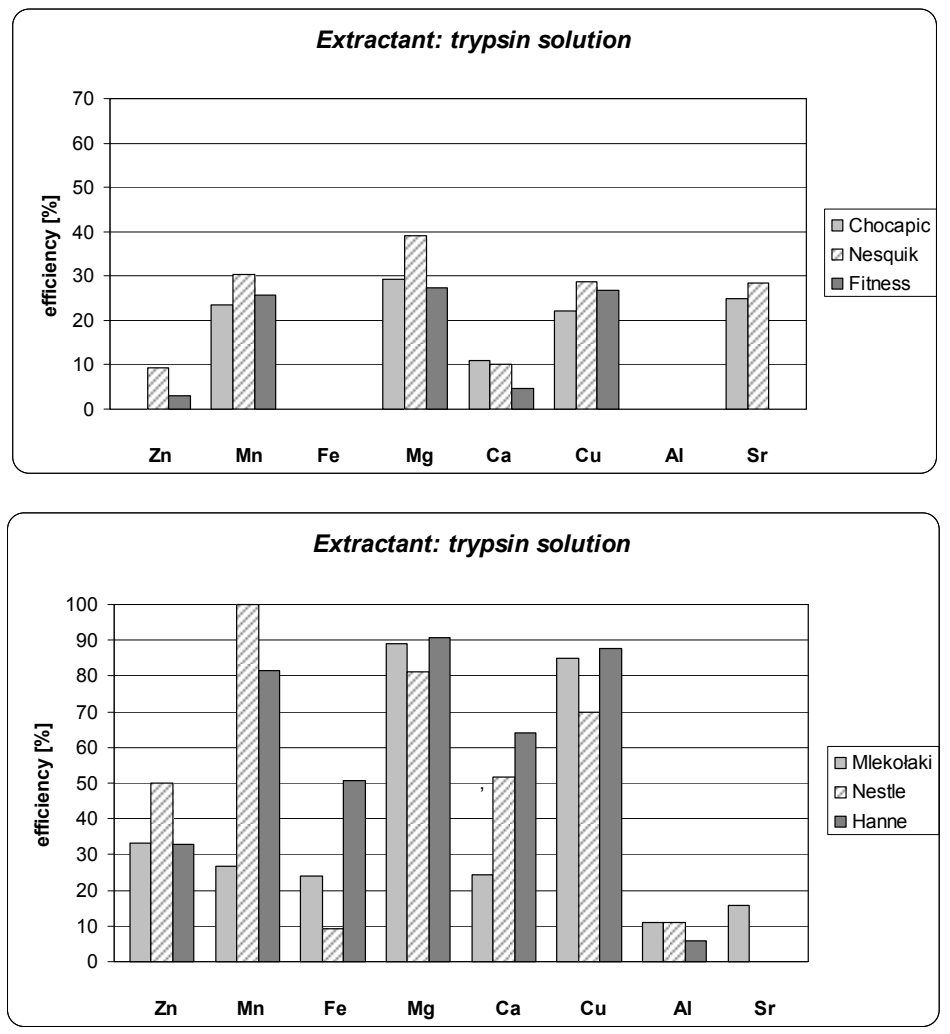

Figure 2. Enzymatic extraction efficiency for trypsin solution 

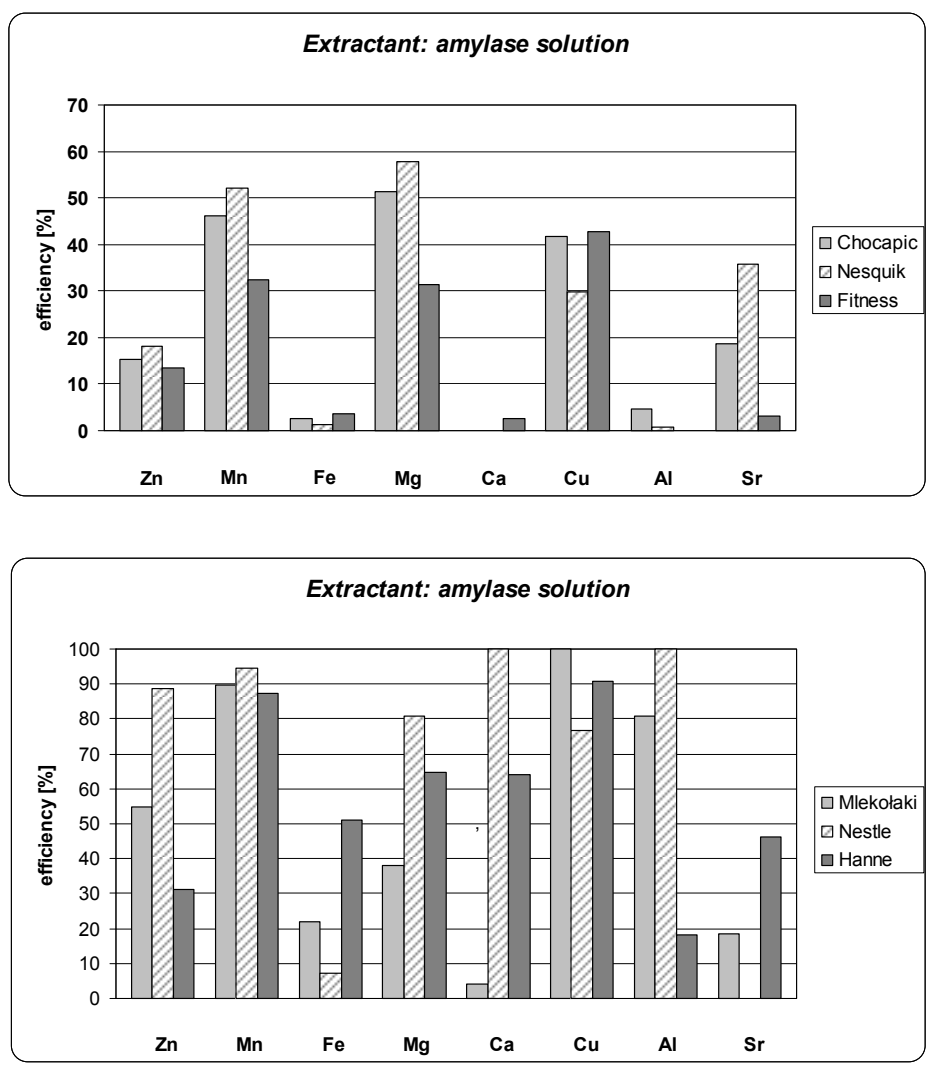

Figure 3. Enzymatic extraction efficiency for amylase solution
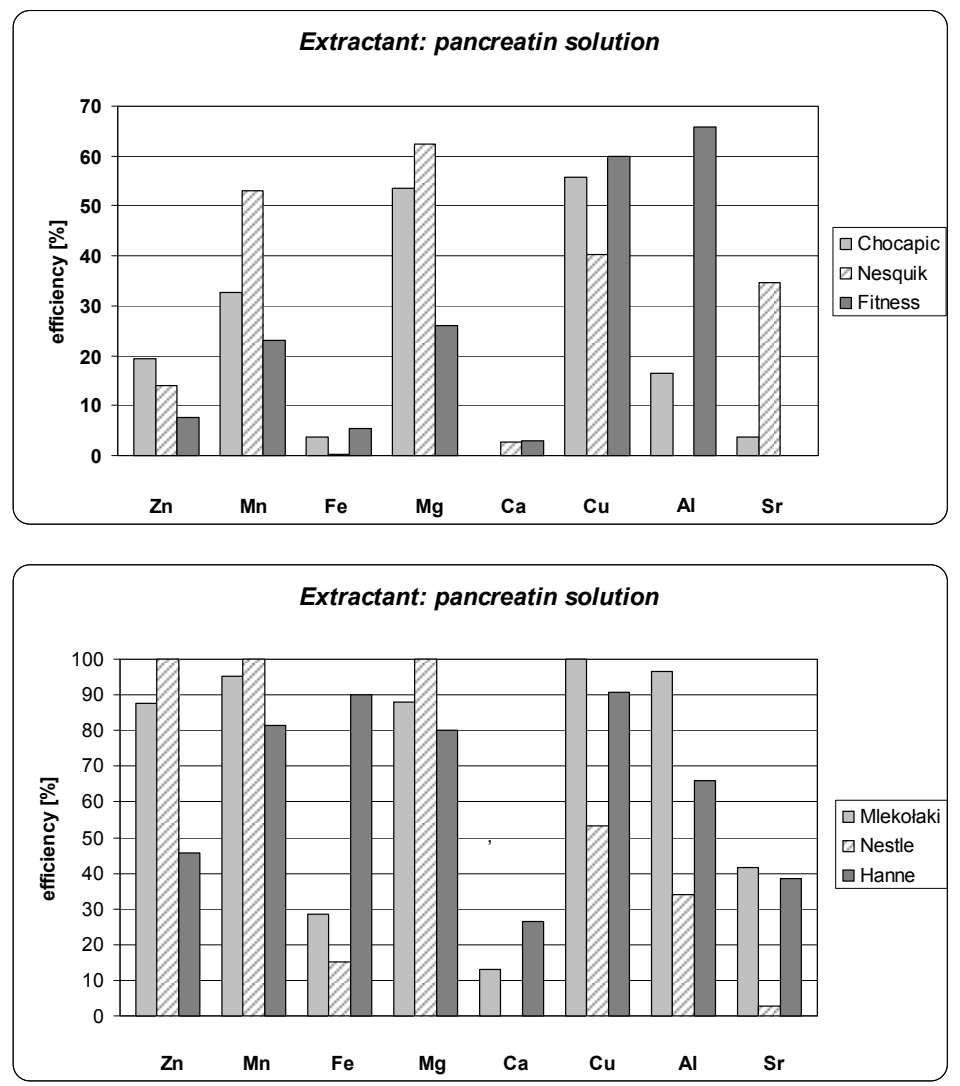

Figure 4. Enzymatic extraction efficiency for pancreatin solution 